\title{
GAMBARAN PSIKOLOGI WARGA KABUPATENMAGELANG SELAMA PANDEMI COVID-19
}

\author{
Muhammad Khoirul Amin ${ }^{1)}$, Sambodo Sriadi Pinilih ${ }^{2)}$, Retna Tri Astuti ${ }^{2)}$ \\ ${ }^{1}$ Program Studi S1 Keperawatan, Universitas Muhammadiyah Magelang. \\ ${ }^{2}$ Dosen Fakultas Ilmu Kesehatan, Universitas Muhammadiyah Magelang \\ Email: khoirulamin@ummgl.ac.id
}

\begin{abstract}
Magelang Regency was ranked first in the case of Covid-19 in Central Java in May 2020. Covid-19 has both physical and psychological impacts. Stress, anxiety and depression are the biggest impacts of the COVID-19 pandemic. This study aims to find out how the psychological view of the residents of Magelang Regency during the covid-19 pandemic. The design of this research is descriptive research, with the aim of knowing the psychological view of the Magelang district community during the covid pandemic. This study was conducted on 62 respondents aged > 15 years in Magelang Regency using the SRQ-29 questionnaire (self-reporting questionnaire-29). From the SRQ-29 which was distributed to the respondents, it was found that there were respondents who had problems with mental emotional disorders, psychotic disorders and PTSD and there were no respondents who used psychotropic substances. During this COVID-19 pandemic, there were respondents who experienced mental emotional disorders, psychotic disorders and also PTSD.
\end{abstract}

Keywords: psychology, residents, covid-19 pandemic

\section{PENDAHULUAN}

Istilah COVID-19 telah diresmikan oleh WHO pada tanggal 11 Februari 2020 yang mana Covid-19 merupakan kepanjangan dari Corona virus Disease 2019(WHO, 2020). Dan sejak pertama kali ditemukan pada akhir 2019, penyakit ini secara resmi dinyatakan sebagai pandemi global olehWHO pada 11 Maret 2020 hal tersebut dikarenakan selama 2 minggu terakhir, jumlah kasus di luar China meningkat $13 \mathrm{kali}$ lipat dan jumlah negara dengan kasus corona meningkat tiga kali lipat(Cucinotta \&Vanelli, 2020).

Kasus COVID-19 pertama di Indonesia didapatkan pada 2 Maret 2020 yaitu seorang pasien perempuan yang melakukan kontak dengan orang Jepang di Jakarta. Dan pada tanggal 31 Maret 2020 didapatkan 1.528 kasus dengan jumlah kematian mencapai 8,9\% (136 kasus). Usia rata-rata penderita yaitu 31-70 tahun dengan jumlah pasien lakilaki lebih banyak dari perempuan(Bakar, Kuncoroaji, Lee, Lee, \& Ningrum, 2020). Dan pada tanggal 9 Mei 2020, di Indonesia terdapat 13.645 kasus COVID-19, dengan 959 kematian dan 2.607 pasien dinyatakan sembuh(Worldometer, 2020). Penyebaran cepat virus ini dikarenakan kurangnya kepatuhan dan ketidakjujuran terhadap tenaga kesehatan(Turista, Islamy, Kharisma, \& Ansori, 2020).

Kabupaten Magelang pernah menduduki peringkat pertama jumlah pasien covid-19seJawa Tengah. Pada tanggal 26 Mei 2020 jumlah pasien covid-19 di Kabupaten Magelang menduduki nomor satu (1) di Jawa Tengah dengan jumlah penderita 65 pasien, kemudian ada Kota Semarang dengan jumlah 62 pasien dan Kabupaten Purworejo dengan 50 penderita(Bsn, 2020).

DOI : https://doi.org/10.51544/jmn.v4i2.1713

(C) 2021 Jurnal Mutiara Ners. This is an open accessarticleunder the CC BY-SA license Website : http://e-journal.sari-mutiara.ac.id/index.php/NERS/index 
Penyakit ini cenderung berpengaruh terhadap pasien yang sudah lanjut dan dapat menyebabkan gangguan pernafasan seperti sindrom pernafasan akut yang mana bias menyebabkan kematian(Chen et al., 2020). Selain dampak fisik tersebut juga berdampak pada kondisi psikologis seperti yang disampaikan oleh (Wang et al., 2020) bahwa selama fase awal wabah COVID-19 di Cina, lebih dari setengah responden menampilkan dampak psikologisnya sedang hingga parah seperti stress, cemas dan depresi. Hal senada juga terjadi di Denmark yang menyampaikan dampak dari pandemic covid ini mengarah ke depresi dan cemas(Sønderskov, Dinesen, Santini, \& Østergaard, 2020).

Penelitian yang dilakukan Jannah (2020) pada 353 responden masyarakat Indonesia dengan menggunakan alat ukur IES-R (Impact of Event Scale-Revised) dan DASS21 (Depression Anxiety Stress Scale-21) untuk mengetahui dampak psikologis covid19. Hasil yang ditemukan yaitu responden yang telah melakukan perjalanan dari daerah Zona merah mengalami dampak psikologis paling banyak. Dan dampak psikologis yang muncul yaitu responden mengalami depresi, stres dan kecemasan.

Berdasarkan studi pendahuluan yang dilakukan pada beberapa orang di kabupaten
Magelang pada bulan Juni-Juli 2020 menyampaikan bahwa adanya covid ini membuat dagangan tidak laku dan bingung mau melakukan apa, di rumah terusmembuat stress, anak-anak sekolah di rumah jadi nambah pekerjaan. Oleh karena itu peneliti tertarik untuk melakukan penelitian dengan judul "Gambaran Psikologis Masyarakat Kabupaten Magelang Selama Pandemi Covid-19"

\section{METODE PENELITIAN}

Desain penelitian yang dilakukan ini adalah penelitian deskriptif, dengan tujuan untuk mengetahui gambaran psikologis pada masyarakat kabupaten Magelang selama pandemic covid yang meliputi, gejala GME (gangguan mental emosional), adanya penggunaan zat psikotropika, gejala psikotik dan gejala gangguan PTSD, serta tingkat stress responden. Populasi dalam penelitian ini adalah warga kabupaten Magelang pada bulan Juli-Agustus dengan jumlah sampel 62 responden. Kuesioner yang digunakan adalah SRQ 29 (self-reporting questionnaire29).

\section{HASIL PENELITIAN}

Tabel 1. Karakteristik Responden $(n=62)$

\begin{tabular}{lccc}
\hline Kategori & & Frekuensi & Prosentase $(\%)$ \\
\hline Jenis Kelamin & & 26 & 42 \\
Laki-laki & & 36 & 58 \\
Perempuan & & & \\
\hline Usia & 21 & 34 \\
Remaja & 16-20 tahun & 34 & 55 \\
Dewasa & $>60$ tahun & 7 & 11 \\
Lansia & & & \\
\hline
\end{tabular}

DOI : https://doi.org/10.51544/jmn.v4i2.1713

(C) 2021 Jurnal Mutiara Ners. This is an open accessarticleunder the CC BY-SA license Website : http://e-journal.sari-mutiara.ac.id/index.php/NERS/index 
Dari table tersebut diketahui banyak jenis kelamin terbanyak adalah 36 (58\%) dan usia terbanyak yaitu dewasa $(55 \%)$

Tabel 2.Respon Psikologi Masyarakat selama Pandemi (n=62)

\begin{tabular}{lcc}
\hline Variebel & Frekuensi & Presentasi (\%) \\
\hline Gejala terbayak Gangguan Mental Emosional & $\mathbf{2 6}$ & $\mathbf{4 2}$ \\
\hline Mudah merasa cemas, tegang atau khawatir & 45 & 72.5 \\
Merasa sulit untuk menikmati aktivitas sehari- & 33 & 53 \\
hari & \multicolumn{2}{c}{43.5} \\
Aktivitas/ tugas sehari-hari terbengkalai & 27 & 40 \\
Kehilangan Nafsu makan & 25 & 37 \\
Tidur tidak nyenyak & 23 & $\mathbf{0}$ \\
\hline Penggunaan Napza & $\mathbf{0}$ & $\mathbf{3}$ \\
\hline Gangguan psikotik & $\mathbf{2}$ & $\mathbf{1 4 . 5}$ \\
\hline Gangguan PTSD & $\mathbf{9}$ & \multicolumn{2}{c}{} \\
\hline
\end{tabular}

Dari table tersebut dapat diketahui bahwa terdapat 26 (42\%) responden yang mengalami gangguan mental emosional dengan gejala terbanyak pada gangguan mental emosional yaitu mudah merasa cemas, tegang atau khawatir (72.5\%), kemudian merasa sulit untuk menikmati aktivitas seharihari (53\%), aktivitas/ tugas sehari-hari terbengkalai (43.5), kehilangan Nafsu makan (40\%) dan tidur tidak nyenyak (37\%). Tidak ada responden yang menggunakan zat narkotika. Terdapat 2 (3\%) responden yang mengalami gangguan psikotik dan $9(14.5 \%)$ responden yang mengalami PTSD.

\section{PEMBAHASAN}

Hasil penelitian menunjukkan bahwaterdapat 26 responden yang mengalami gangguan mental emosional dengan keluhan merasa cemas, tegang atau khawatir $(72.5 \%)$, merasa sulit menikmati aktivitas sehari-hari (53\%), aktivitas sehari-hari terbengkalai (43.5\%), kehilangan nafsumakan $(40 \%)$ dan tidur tidak nyenyak (37\%).

(Choi, Hui, \& Wan, 2020) dalam penelitiannya dengan judul Depression and Anxiety in Hong Kong during COVID-19 bahwadari 500 responden bahwa $19 \%$ mengalami depresi dan 14\% mengalami cemas. Hal senada disampaikan Özdin, S., \& Bayrak Özdin, Ş. (2020) bahwa wargaTurki juga mengalami depresi dan cemas dengan adanya covid-19 ini. Dengan kekhawatiran dan kecemasan yang terus berkembang selama covid-19 ini direkomendasikan perawatan diri terutama kesehatan mental yang efektif(Sønderskov et al., 2020)

Survei lain dilakukan pada 1491 responden dengan usia dewasa, dimana $67 \%$ perempuan didapatkan data perubahan negative untuk aktivitas fisik (48,9\%), gangguan tidur $(40,7 \%)$, menggunakan alkohol $(26,6 \%)$ dan merokok $(6,9 \%)$ sejak dimulainya pandemi COVID-19. Perubahan negative dalam aktivitas fisik, tidur, merokok, dan asupan alcohol dikaitkan dengan gejala depresi, kecemasan, dan stres yang lebih tinggi(Stanton et al., 2020). Hal lain disampaikan(C.H.Liu, Stevens, Conrad, \& Hahme, 2020) bahwa adanya covid-19 menimbulkan gejala depresi, kecemasan, khwatir, masalah tidur dan kualitas hidup. Sedangkan(Cecchetto, Aiello, Gentili, Ionta,

DOI : https://doi.org/10.51544/jmn.v4i2.1713

(C) 2021 Jurnal Mutiara Ners. This is an open accessarticleunder the CC BY-SA license Website : http://e-journal.sari-mutiara.ac.id/index.php/NERS/index 
\& Osimo, 2020) menyebutkan bahwa adanya isolasi social selama pandemic covid dapat menyebabkan masalah emosional dan penurunan makan.

(Dubey et al., 2020) dalam literature reviewnya tentang Psychosocial impact of COVID-19 didapatkan data bahwa adanya covid-19 yang mengharuskan isolasi mandiri dapat menimbulkan kepanikan akut, kecemasan, perilaku obsesif, penimbunan, paranoia dan depresi. Sedangkan literature review tentang Prevalence of depression, anxiety, and insomnia among healthcare workers during the COVID-19 pandemic yang dilakukan oleh (Pappa et al., 2020) didapatkan data bahwa dari 13 artikel yang ditelaah terdapat 12 artikel mengatakan dampak kecemasan, 10 artikel dengan depresi dan insomnia terdapat pada 5 artikel.

Jadi adanya covid-19 dapat menyebabkan gangguan mental emosional kecemasan dan depresi dengan beberapa gejala yaitu, merasa cemas dan khawatir, aktivitas menurun, mengalami gangguan tidur, penurunan nafsu makan, penggunaanalcohol dan merokok.

Hasil penelitian didapatkan bahwa tidak terdapat yang menggunakan zatpsikotropika. Sedangkan hasil lain yaitu terdapat 2 responden yang mengalami gangguan psikotik. Pandemi covid-19 menimbulkan gejala neuro psikiatri pada beberapa responden, seperti perubahan suasana hati, psikosis dan disfungsi neuromuskuler(Troyer, Kohn, \& Hong, 2020). Sembilan dari 10 kasus menunjukkan gejala psikotik setidaknya dua minggu setelah manifestasisomatik pertama yang berhubungan dengan covid-19 dan telah menerima perawatan farmakologis dengan presentasi klinis tersering yaitu delusi dan kebingungan(Parra et al., 2020). Jadiadanya pandemic covid-19 dapat menimbulkan masalah psikologis.
Hasil penelitian didapatkan bahwa terdapat 9 responden dengan masalah PTSD (Post Traumatic Stress Disorders). Covid-19 dapat memberikan dampak PTSD yangdisebabkan adanya penyebaran "infodemik" melaluiberbagai media, ledakan rasisme, stigmatisasi, dan xenophobia terhadap komunitas tertentu(Dubey et al., 2020). (Carmassi et al., 2020) menyampaikan dengan adanya covid-19 dan membuat tenaga kesehatan memunyai resiko besar tertular penyakit ini, jadi sebagian besar petugas kesehatan memiliki risiko lebihbesar untuk mengalami PTSD. Sedangkan(Tang et al., 2020) menyebutkan prevalensi PTSD dan depresi ditemukan $2,7 \%$ dan $9,0 \%$ pada 2485 mahasiswa dari 6 universitas yang dikarantina. Secara subyektif, perasaan takut yang ekstrem adalah factor risiko paling signifikan untuk tekanan psikologis, diikuti oleh durasi tidur yang singkat dan tinggal di daerah yang terkena dampak parah.

Jadi adanya pandemic covid-19 juga dapat menimbulkan gejala PTSD baik tenaga kesehatan maupun masyarakat umum.

\section{KESIMPULAN}

Hasil penelitian bahwa pandemic covid-19 memberikan dampak psikologis berupa gangguan mental emosional dengan gejala cemas, tegang, khawatir, sulit melakukan aktivitas sehari-hari, aktivitas menjadi terbengkalai, kehilangan nafsu makan dan tidur tidak nyenyak. Selain itu juga berdampak timbulnya gangguan psikotikdan PTSD.

\section{SARAN}

Dari hasil tersebut perlu tindakan untuk mengatisipasi masalah psikologi terutama gangguan psikotik. 


\section{REFERENSI}

Bakar, A., Kuncoroaji, T. I., Lee, A., Lee, S.-C., \& Ningrum, V. (2020). Epidemiological Characteristics ofEarly COVID-19 Case Outbreaks in Indonesia. Basel: MDPI AG.

Bsn. (2020). Kabupaten Magelang Peringkat Satu Jumlah Pasien Covid-19 SeJateng. Retrieved from https://borobudurnews.com/kabupatenmagelang-peringkat-satu-jumlahpasien-covid-19-se-jateng/

C.H.Liu, Stevens, C., Conrad, R. C., \& Hahme, H. C. (2020). Evidence for elevated psychiatric distress, poorsleep, and quality of life concerns during the COVID-19 pandemic among

U.S. young adults with suspected and reported psychiatric diagnoses. Psychiatry Research, 292, 113345. https://doi.org/10.1016/j.psychres.2020. 113345

Carmassi, C., Foghi, C., Dell'Oste, V., Cordone, A., Bertelloni, C. A., Bui, E., \& Dell'Osso, L. (2020). PTSD

symptoms in healthcare workers facing the three coronavirus outbreaks: What can we expect after the COVID-19 pandemic. Psychiatry Research, 292(113312).

https://doi.org/10.1016/j.psychres.2020. 113312

Cecchetto, C., Aiello, M., Gentili, C., Ionta, S., \& Osimo, S. A. (2020). Increased emotional eating during COVID-19 associated with lockdown, psychological and social distress. Appetite, $160, \quad 105122$. https://doi.org/10.1016/j.appet.2021.10 5122
Chen, N., Zhou, M., Dong, X., Qu, J., Gong, F., Han, Y., ... Zhang, L. (2020). Epidemiological and clinical characteristics of 99 cases of 2019 novel coronavirus pneumonia inWuhan, China: a descriptive study. TheLancet, 395(10223), 507-513. https://doi.org/10.1016/S01406736(20)30211-7

Choi, E. P. H., Hui, B. P. H., \& Wan, E. Y. F. (2020). Depression and Anxiety in Hong Kong during COVID-19. International Journal of Environmental Research and Public Health, 17(10), 3740.

https://doi.org/10.3390/ijerph17103740

Cucinotta, D., \& Vanelli, M. (2020). WHO declares COVID-19 a pandemic. Acta Bio Medica: Atenei Parmensis, 91(1), 157-160.

Dubey, S., Biswas, P., Ghosh, R., Chatterjee, S., Dubey, M. J., Chatterjee, S., ... Lavie, C. J. (2020). Psychosocial impact of COVID-19. Diabetes \& Metabolic Syndrome, 14(5), 779-788. https://doi.org/10.1016/j.dsx.2020.05.0 35

Pappa, S., Ntella, V., Giannakas, T., Giannakoulis, V. G., Papoutsi, E., \& Katsaounou, P. (2020). Prevalence of depression, anxiety, and insomnia among healthcare workers during the COVID-19 pandemic: A systematic review and meta-analysis. Brain, Behavior, and Immunity, 88, 901-907. https://doi.org/10.1016/j.bbi.2020.05.02 6

Parra, A., Juanes, A., Losada, C. P., ÁlvarezSesmero, S., Santana, V. D.,Martí, I., ... Rentero, D. (2020).

DOI : https://doi.org/10.51544/imn.v4i2.1713

(c) 2021 Jurnal Mutiara Ners. This is an open accessarticleunder the CC BY-SA license Website : http://e-journal.sari-mutiara.ac.id/index.php/NERS/index 
Psychotic symptoms in COVID-19 patients. A retrospective descriptive study. Psychiatry Research, 291(113254).

https://doi.org/10.1016/j.psychres.2020. 113254

Sønderskov, K. M., Dinesen, P. T., Santini, Z. I., \& Østergaard, S. D. (2020). The depressive state of Denmark during the COVID-19 pandemic. Acta Neuropsychiatrica, 32(4), 226-228.

Stanton, R., To, Q. G., Khalesi, S., Williams, S. L., Alley, S. J., Thwaite, T. L., ... Vandelanotte, C. (2020).

Depression, Anxiety and Stress during COVID-19: Associations with Changes in Physical Activity, Sleep, Tobacco and Alcohol Use in Australian Adults. International Journal of Environmental Research and Public Health, 17(11), 4065.

https://doi.org/10.3390/ijerph17114065

Tang, W., Hu, T., Hu, B., Jin, C., Wang, G., Xie, C., ... Xu, J. (2020). Prevalence and correlates of PTSD and depressive symptoms one month after the outbreak of the COVID-19 epidemic in a sample of home-quarantined Chineseuniversity students. Journal of AffectiveDisorders, 274, $\quad 1-7$. https://doi.org/10.1016/j.jad.2020.05.00 9

Troyer, E. ., Kohn, J. N., \& Hong, S. (2020). Are we facing a crashing wave of neuropsychiatric sequelae of COVID19? Neuropsychiatric symptoms and potential immunologic mechanisms. Brain, Behavior, and Immunity, 87, 3439. https://doi.org/10.1016/j.bbi.2020.04.02 7
Turista, D. D. R., Islamy, A., Kharisma, V. ., \& Ansori, A. N. M. (2020).

Distribution of COVID-19 and phylogenetic tree construction of SARS$\mathrm{CoV}-2$ in Indonesia. $J$ Pure Appl Microbiol, 14(1), 1035-1042.

Wang, C., Pan, R., Wan, X., Tan, Y., Xu, L., S., C., \& Ho, R. C. (2020). Immediate psychological responses and associated factors during the initial stage of the 2019 coronavirus disease (COVID-19) epidemic among the general population in China. International Journal of Environmental Research and Public Health, 17(5), 1729.

WHO. (2020). WHO Director-General's remarks at the media briefing on 2019$n \mathrm{CoV}$. Geneva: World Health Organization.

Worldometer. (2020). Coronaviruses cases.

DOI : https://doi.org/10.51544/imn.v4i2.1713

(c) 2021 Jurnal Mutiara Ners. This is an open accessarticleunder the CC BY-SA license Website : http://e-journal.sari-mutiara.ac.id/index.php/NERS/index 